Огляди літератури, оригінальні дослідження, погляд на проблему

УДК 616.72 - 007.24: 616.12-008.331.1]-056.257-036-092: 577.121

DOI

\title{
ОСОБЛИВОСТІ МЕТАБОЛІЗМУ СПОЛУЧНОЇ ТКАНИНИ ТА ПРОЗАПАЛЬНИХ ЦИТОКІНІВ У ПАЦІЕНТІВ З ОСТЕОАРТРОЗОМ ТА КОМОРБІДНИМИ ГІПЕРТОНІЧНОЮ ХВОРОБОЮ ТА ОЖИРІННЯМ
}

\author{
๑О. С. Хухліна, О. В. Танас \\ Буковинський державний медичний університет
}

\begin{abstract}
РЕЗЮМЕ. У статті викладено результати дослідження показників обміну сполучної тканини та прозапальних цитокінів у хворих на остеоартроз з коморбідними есенціальною артеріальною гіпертензією та ожирінням. Встановлено, що перебіг остеоартрозу супроводжується підвищенням активності системного запалення, інтенсивність якого за наявності супутніх гіпертонічної хвороби та ожиріння вірогідно зростає. У хворих на остеоартроз вміст прозапальних цитокінів у крові $\epsilon$ вірогідно підвищеним і зростає із приєднанням ожиріння.

КЛЮчОВІ СЛОВА: остеоартроз, артеріальна гіпертензія, ожиріння, сполучна тканини, цитокіни.
\end{abstract}

Вступ. Остеоартроз (ОА) сьогодні належить до числа найпоширеніших захворювань суглобів, які супроводжуються зниженням якості життя та втратою працездатності. Остеоартроз часто поєднується з есенціальною артеріальною гіпертензією (АГ) та ожирінням (ОЖ) за даними вітчизняних (Березняков И. Г., Корж И. В.; Головач И. Ю.) та іноземних вчених (S. Casteda, J. A. Roman-Blas, R. Largo, G. Harrero-Beaumont; M. Bijsma, F. Berenbaum, F. P Lafeber; M. Magliano) $[1,2,6,7,10]$.

Згідно з сучасними поглядами, цитокіни інтерлейкін - $1 \beta$ (ІЛ-1 $\beta)$ та фактор некрозу пухлин- $\alpha$ $(Ф Н П \alpha)$ відіграють важливу роль у патогенезі «запальної» теорії розвитку ОА $[2,10,11,13]$. При ОА хондроцити експресують рецептори до ІЛ- $1 \beta$, що підвищує їх чутливість до цитокіну, під впливом якого хондроцити синтезують протеолітичні ферменти - матриксні протеази - агресивний фактор деградації колагену і протеогліканів хряща $[3,7]$. Останнім часом з'явились дані про певні фенотипи перебігу ОА $[2,9]$. Найпоширенішими фенотиповими варіантими ОА $\epsilon$ вік-асоційований, естрогенозалежний, генетично детермінований, больовий, посттравматичний, кристалоіндукований ОА (внаслідок відкладання кристалів уратів натрію, пірофосфатів кальцію дигідрату) та метаболічний, які відрізняються патогенетичними процесами і клінічними проявами $[2,8,9]$. Одним з поширених фенотипів ОА $є$ метаболічний, який пов'язують з метаболічним синдромом та запаленням низької інтенсивності. Зацікавленість науковців викликає пошук взаємозв'язків між компонентами метаболічного синдрому, активністю прозапальних цитокінів та станом обміну сполучної тканини у хворих на ОА.

Метою нашого дослідження було визначення показників обміну сполучної тканини та прозапальних цитокінів у хворих на ОА з коморбідними есенціальною АГ та ОЖ.
Матеріал і методи дослідження. Обстежено 90 пацієнтів, які були поділені на три групи: I групу (n=30) склали хворі, які страждають на ОА колінних суглобів II-III стадії за Kellgren i Lawrense без супутньої патології, II групу $(n=30)$ - пацієнти з ОА колінних суглобів II-III стадії за Kellgren i Lawrense та супутньою есенціальною АГ ІІ стадії, 2 ступеня без ожиріння, III групу ( $=30)$ - пацієнти з ОА колінних суглобів II-III стадії за Kellgren i Lawrense, есенціальною АГ II стадії, 2 ступеня i ожирінням I ступеня. Середній вік хворих складав $(62,3 \pm 5,7)$ років.

Стадію ОА визначали відповідно до рентгенологічної класифікації Kellgren i Lawrense. Контрольну групу склали 20 здорових осіб відповідного віку. Зміни метаболізму компонентів сполучної тканини визначали за вмістом у крові вільного оксипроліну (за методом С. С. Тетянец, 1985; М. А. Осадчуком, 1979), сіалових кислот (В. Г. Колб, В. С. Камышников, 1976). Вміст ФНП- $\alpha$, ІЛ-1 $\beta$, ІЛ-6 у сироватці крові визначали методом ІФА за допомогою діагностичних наборів ООО «Вектор-Бест» (г. Новосибирск, Россия). Статистичну обробку проводили за допомогою пакета Statistica 7.0.

Результати й обговорення. Отримані дані свідчать, що у хворих I групи, порівняно з групою контрольних осіб, рівень оксипроліну в крові був підвищений у 1,4 раза $(p<0,05)$, а сіалових кислот у 1,5 раза $(p<0,05)$. Водночас у пацієнтів I групи встановлено підвищений рівень ФНП-а у 1,9 раза $(p<0,05)$, ІЛ-1 $\beta$ у 3 рази та ІЛ-6 - у 2,3 раза $(p<0,05)$ відповідно до ПЗО, що свідчить про активацію імунозапальних порушень в організмі пацієнтів, які страждають на остеоартроз, навіть без супутньої патології. А проведення аналізу цих показників між групами хворих з ОА дозволило встановити достовірне збільшення вмісту у сироватці крові компонентів сполучної тканини та прозапальних 
Огляди літератури, оригінальні дослідження, погляд на проблему цитокінів залежно від наявності коморбідної патології (табл. 1). Так, рівень оксипроліну у пацієнтів III групи перевищив аналогічний у II групі в 1,5 раза ( $<<0,05)$ і в I групі 1,6 раза $(p<0,05)$; рівень сіалових кислот у III групі був у 2,7 раза більшим, ніж у II групі $(p<0,05)$, і в 3,7 раза більшим за показник І групи (p<0,05). Очевидно, що при ОА відбувається активація катаболізму структурних компонен-

тів екстрацелюлярного матриксу, яка зумовлена гіперекспресією низки протеолітичних ферментів. Таким чином, відбувається деградація колагенових фібрил, які складаються в основному із колагену I типу. Особливо ці процеси можуть активуватися внаслідок дії адипокінів, які секретуються жировою тканиною і впливають на функцію хрящової і кісткової тканин [4, 12].

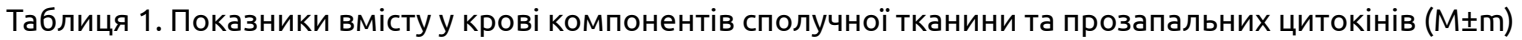

\begin{tabular}{|l|c|c|c|c|}
\hline \multicolumn{1}{|c|}{ Показники } & ПзО, $\mathrm{n}=20$ & І група, $\mathrm{n=30}$ & II група, $\mathrm{n}=30$ & III група, $\mathrm{n}=30$ \\
\hline Оксипролін, мкмоль/л & $9,08 \pm 0,4$ & $12,16 \pm 0,79^{*}$ & $13,05 \pm 1,02^{*}$ & $19,80 \pm 2,01^{*} / * * / * * *$ \\
\hline Сіалові кислоти, ммоль/мл & $2,2 \pm 0,2$ & $3,4 \pm 0,08^{*}$ & $4,80 \pm 1,03^{*}$ & $12,76 \pm 2,64^{*} / * * / * * *$ \\
\hline ФНП- $\alpha$, пг/мл & $2,59 \pm 0,6$ & $4,91 \pm 0,08^{*}$ & $11,80 \pm 2,09^{*} / * *$ & $31,77 \pm 2,3 * / * * / * * *$ \\
\hline ІЛ-1, пг/мл & $3,45 \pm 0,6$ & $10,07 \pm 2,63^{*}$ & $22,8 \pm 1,6 * / * *$ & $49,5 \pm 2,33^{*} / * * / * * *$ \\
\hline ІЛ-6, пг/мл & $5,27 \pm 1,3$ & $12,43 \pm 1,3^{*}$ & $26,6 \pm 4,5^{*} / * *$ & $53,45 \pm 2,18^{*} / * * / * * *$ \\
\hline
\end{tabular}

Примітки: 1. *-різниця вірогідна упорівнянніз показникомупрактично здоровихосіб (р<0,05); 2 . ** - різниця вірогідна упорівнянні з показником у хворих 1 групи (p<0,05); 3. ***- різниця вірогідна у порівнянні з показником у хворих 2 групи (р<0,05).

Рівень ФНП-а у пацієнтів III групи перевищив у 2,7 раза $($ р<0,05) показник II групи та в 6,5 раза І групи (p<0,05). Відомо, що ФНП- $\alpha$ має рецептори на хондроцитах, $\epsilon$ активатором запалення й тканинного пошкодження при ОА, стимулює синтез простагландинів, фактора активації тромбоцитів, супероксидних радикалів, металопротеїназ, індукує синтез інших прозапальних цитокінів (ІЛ-1, ІЛ-6, ІЛ-8 та ін.) $[5,11,12]$. Вміст ІЛ-1 $\beta$ у пацієнтів III рупи був статистично вірогідно вищий у 2,0 рази $(p<0,05)$, ніж у II групі та в 5 разів $(p<0,05)$ - ніж у І групі. Такі зміни цитокінового профілю пов'язані із розвитком запального процесу у суглобах, адже ІЛ-1 стимулюєсинтез простагландинів та лейкотрієнів [5-7, 10]. При ОА ІЛ-1 зумовлює проліферацію фібробластів і синтез колагенази в синовіальних оболонках суглобів, а також індукує синтез ІЛ-6 неспецифічного медіатора, який є основним індуктором реакції гострої фази запалення. Ці інтерлейкіни $€$ первинними медіаторами, які запуска-

\section{ЛІТЕРАТУРА}

1. Березняков И. Г. Остеоартроз, артериальная гипертензия и ожирение: проблема коморбидности / И. Г. Березняков, И. В. Корж // Международный мед. журнал. - 2012. - № 4. - С. 78-81.

2. Головач И. Ю. Остеоартрит: современные фундаментальные и прикладные аспекты патогенеза заболевания / И. Ю.Головач // Боль. Суставы. Позвоночник. - 2014. - № 3 (15). - С. 54-58

3. Дубиков А. И. Остеоартроз: старая болезнь, новые подходы / А. И. Дубиков // Совр. ревматология. 2013. - № 2. - С. 82-83.

4. Опімах О. І Вивчення активності системного запалення у хворих на остеоартроз-асоційований з ожирінням / О. І. Опімах // Патологія. - 2010. - № 3 (7). C. $110-112$ ють механізм деградації хондроцитів суглобового хряща при ОА $[5,7,10,11,13]$. Проведений аналіз одержаних даних вказує на те, що при ожирінні продукується підвищена кількість прозапальних цитокінів, які спричиняють апоптоз та руйнування хондроцитів. Вищезазначене дозволяє припустити, що це відбувається через стимуляцію синтезу та виділення в кров прозапальних цитокінів.

Висновки. Перебіг остеоартрозу супроводжується підвищенням активності системного запалення, інтенсивність якого за наявності супутньої патології ЕАГ та ОЖ вірогідно зростає. У хворих на остеоартроз вміст прозапальних цитокінів у крові $\epsilon$ вірогідно підвищеним і зростає із приєднанням ожиріння.

Перспективи подальших досліджень полягають у вивченні взаємозв'язку між клінічними проявами остеоартрозу, рівнем артеріального тиску та станом компонентів сполучної тканини і прозапальних цитокінів.

5. Танас О. В. Динаміка показників цитокінового та оксидантного гомеостазу при лікуванні діацереїном у пацієнтів з остеоартрозом та коморбідними захворюваннями / О. В. Танас, О. С. Хухліна // Вісник проблем біології і медицини. - 2014. - № 3, Т. 2 (111). - С. 241-245.

6. Танас О. В. Сучасна терапія остеоартрозу за коморбідності з артеріальною гіпертензією та ожирінням / О. В. Танас, О. С. Хухліна // Матеріали 96-ї підсумкової наукової конференції професорсько-викладацького персоналу Буковинського державного медичного університету (Чернівці, 16, 18, 23 лютого 2015 р.). - Чернівці : БДМУ, 2015. - С. 107-108.

7. Increased interleukin-1 $\beta$ gene expression in peripheral blood leukocytes is associated with increased pain and predicts risk for progression of symptomatic knee 
Огляди літератури, оригінальні дослідження, погляд на проблему

osteoarthritis / M. Attur, I. Belitskaya-Levy, C. Oh [et. al] // Arthritis Rheum. - 2011. - Vol. 63, № 7. - P. 1908-1917.

8. Bijsma M. Osteoarthritis: an update with relevance for clinical practice / M. Bijsma, F. Berenbaum, F. P. Lafeber // Lancet. - 2011. - Vol. 377. - P. 2115-2126.

9. Osteoartritis: a progressive disease with chaning phenotypes / S. Casteda, J. A. Roman-Blas, R. Largo, G. HarreroBeaumont // Rheumatology. - 2013. - №6. - C. 258-260.

10. Sokolove J. Role of inflammation in the pathogenesis of osteoarthritis: latest finding and interpretations /
J. Sokolove, Ch. M. Lepus // Ther. Adv. Musculoskel. Dis. 2013. - Vol. 5, № 2. - P. 77-94.

11. Goldring M. B. Inflammation in osteoartritis / M. B. Goldring, M. Otero // Curr. Opin.Rheumatol. - 2011. Vol. 23, № 5. - P. 471-478.

12. Magliano M. Obesity and arthritis / M. Magliano // Menopause Int. - 2008. - Vol. 14. - P. 149-154.

13. Role of proinflammatory cytokines in the pathophysiology of osteoarthritis / M. Kapoor [et all.] // Nat. Rev. Rheumatol. - 2011. - Vol. 7, № 1. - P. 33-42.

\title{
THE PECULIARITIES OF CONNECTIVE TISSUE AND INFLAMMATORY CYTOKINES METABOLISM IN PATIENTS WITH OSTEOARTHRITIS, COMORBID HYPERTENSION AND OBESITY
}

\author{
๑O. S. Khukhlina, O. V. Tanas
}

\section{Bukovynian State Medical University}

SUMMARY. In the paper the research results of changes of the connective tissue and inflammatory cytokines metabolism in patients with comorbid osteoarthritis, essential hypertension and obesity are presented. The osteoarthritis course is accompanied by increased activity of systemic inflammation, the intensity of systemic inflammation is significantly higher in case of the presence of comorbidities: hypertension and obesity. In patients with osteoarthritis the content of inflammatory cytokines in the blood is likely higher and increases even more when combined with comorbid obesity.

KEY WORDS: osteoarthritis, arterial hypertension, obesity, connective tissue, inflammatory cytokines.

Отримано 4.04.2016 